\title{
"WAT IS WAARHEID?"
}

\author{
Hans-Georg Gadamer
}

Onmiddellijk naar de betekenis van de historische situatie verstaan, hangt de vraag van Pilatus "Wat is waarheid ?" (Joh. 18, 38) met het neutraliteitsprobleem samen. Zoals dit gezegde in de staatsrechterlijke situatie van het toenmalige Palestina door de procurator Pontius Pilatus uitgesproken wordt, betekent het dat wat door een man als Jezus als waarheid uitgegeven wordt, de staat helemaal niets aangaat. De liberale en tolerante houding die het staatsgezag daarmee tegenover de situatie aanneemt, heeft iets zeer merkwaardigs. Tevergeefs zouden we naar iets gelijkaardigs uitkijken in het antieke en zelfs moderne politieke leven tot en met de dagen van het liberalisme. Het is de bijzondere staatsrechterlijke situatie van het staatsgezag dat tussen een joodse 'koning' en een Romeinse procurator balanceert, die zo'n houding van verdraagzaamheid eigenlijk mogelijk maakte. Wellicht is het politieke aspect van de verdraagzaamheid steeds zó, dan bestaat de politieke taak die het ideaal van de verdraagzaamheid stelt, er juist in dergelijke toestanden van evenwicht binnen de staatsmacht tot stand te brengen.

Het zou een illusie zijn te menen dat dit probleem zich in de moderne staat niet meer stelt, omdat deze staat de vrijheid van de wetenschap principieel erkent. Want daar een beroep op doen, blijft steeds een gevaarlijke abstractie. De onderzoeker is niet van zijn politieke verantwoordelijkheid ontslagen zodra hij uit de stilte van zijn studeerkamer of uit zijn laboratorium, waar onbevoegden geen toegang hebben, naar buiten treedt en zijn kennis publiek maakt. Zo onvoorwaardelijk en ondubbelzinnig de waarheidsidee het leven van de onderzoeker beheerst, zo beperkt en dubbelzinnig is immers de onverholenheid waarmee hij spreekt. Hij moet de uitwerking van zijn woord kennen en kunnen verantwoorden. De demonische keerzijde van deze samenhang is echter dat hij met het oog op deze uitwerking in de verleiding komt, dat te zeggen - ja, als waarheid zichzelf wijs te maken - wat hem in werkelijkheid de publieke opinie of de belangen van de staatsmacht dicteren. Er is hier een interne samenhang tussen de beperking van de meningsuiting en de onvrijheid in het denken zelf. We willen voor onszelf niet verbergen, dat de vraag "Wat is waarheid ?" in de zin waarin 
Pilatus ze stelde, vandaag nog ons leven bepaalt.

Er bestaat echter nog een andere toonaard waarin we deze uitspraak van Pilatus gewoon zijn te horen, de toonaard waarin Nietzsche hem gehoord heeft, als hij beweert dat het eigenlijk de enige uitspraak van het Nieuwe Testament is die waarde heeft. Volgens hem spreekt uit het gezegde van Pilatus een sceptische afwijzing van de 'ijveraar'. Nietzsche heeft hem niet toevallig geciteerd. Want ook zijn eigen kritiek op het christendom van zijn tijd is de kritiek van een psycholoog op de ijveraar.

Nietzsche heeft deze scepsis toegespitst tot een scepsis tegen de wetenschap. De wetenschap heeft inderdaad dit met de ijveraar gemeen dat zij, omdat zij steeds bewijzen verlangt en bewijzen geeft, even onverdraagzaam is als hij. Niemand is zo onverdraagzaam als wie wil bewijzen dat wat hij zegt het ware moet zijn. Volgens Nietzsche is de wetenschap intolerant, omdat zij een symptoom van de zwakke zonder meer is, een laat product van het leven, een alexandrijnerdom, erfgenaam van die decadentie die Sokrates, de uitvinder van de dialectiek, in een wereld bracht waarin er nog geen 'onfatsoenlijkheid van het bewijzen' bestond, maar waarin een voorname zelfzekerheid zonder bewijzen bepaalt en spreekt.

Deze psychologische scepsis tegen de waarheidsaanspraak treft weliswaar niet de wetenschap zelf. Daarin zal niemand Nietzsche volgen. Maar er bestaat inderdaad ook een twijfel aan de wetenschap als zodanig, die zich voor ons op een derde niveau achter de uitspraak "Wat is waarheid ?" verheft. Is de wetenschap werkelijk, zoals ze voor zichzelf opeist, de laatste instantie en de enige drager van de waarheid ?

We hebben aan de wetenschap bevrijding van vele vooroordelen en ontnuchtering tegenover vele illusies te danken. Steeds weer is het de aanspraak van de wetenschap, ononderzochte vooroordelen twijfelachtig te maken en op deze manier wat is, beter te kennen, dan dat het tot nu toe gekend werd. Tegelijk is het echter voor ons - hoe verder de werkwijze van de wetenschap zich over al wat is, uitbreidt - des te twijfelachtiger geworden, of, vanuit de vooronderstellingen van de wetenschap, de waarheidsvraag wel in haar volle draagwijdte toegelaten wordt. We vragen ons bezorgd af: in hoeverre ligt het juist aan de werkwijze van de wetenschap, dat er zoveel vragen bestaan waarop we een antwoord moeten weten en die ze ons nochtans verbiedt ? Ze verbiedt ze echter doordat ze ze in diskrediet brengt, dat wil zeggen voor zinloos verklaart. Want zin heeft slechts voor haar, wat aan haar eigen methode om de waarheid te ontdekken en te onderzoeken voldoet. Dit onbehagen ten opzichte van de waarheidsaanspraak door de wetenschap komt vooral in de godsdienst, de filosofie en de wereldbeschouwing op. $Z \mathrm{Zij}$ zijn de instanties waarop de sceptici tegenover de wetenschap zich beroepen, om de grens van de wetenschappelijke specialisatie en de grens van het methodisch onderzoek ten opzichte van de beslissende levens- 
vragen te markeren.

Nadat we zo in een inleiding de vraag van Pilatus op haar drie niveaus overlopen hebben, wordt het duidelijk dat het laatste niveau, waarop de interne relatie tussen wetenschap en waarheid problematisch wordt, voor ons het belangrijkste is. Zo komt het er nu allereerst op aan, het feit naar waarde te schatten, dat de waarheid met de wetenschap een zo bevoorrechte binding aangegaan is.

\section{Wetenschap en waarheid}

Dat het de wetenschap is die de beschaving van het avondland in haar specifieke vorm en spoedig ook in haar beheersende eenheid uitmakt, ziet iedereen. Maar als men deze samenhang wil begrijpen, dan moet men tot de oorsprongen van deze wetenschap van het avondland, dit wil zeggen tot haar Griekse herkomst teruggaan. De Griekse wetenschap is iets nieuws ten opzichte van alles wat de mensen vroeger wisten en als weten beoefenden. Toen de Grieken deze wetenschap ontwikkelden, hebben ze het avondland van het Oosten gescheiden en op zijn eigen weg gebracht. Het was een unieke drang naar kennis, inzicht, onderzoek van het onbekende, het vreemde, het wonderbare, en een even unieke scepsis tegen al wat er verteld en voor waar uitgegeven wordt, die hen ertoe bewogen heeft, de wetenschap te scheppen. Als leerrijk voorbeeld kan hier een scène uit Homeros dienen. Aan Telemachos wordt gevraagd, wie hij is; daarop antwoordt hij: mijn moeder heet Penelope, maar wie mijn vader is, dat kan men immers nooit precies weten. De mensen zeggen dat het Odysseus is. Zo'n scepsis, die tot het uiterste gaat, openbaart de bijzondere begaafdheid van de Griekse mens om de directheid van zijn kennisdrang en van zijn verlangen naar waarheid verder tot de wetenschap te ontwikkelen.

Een treffend inzicht kwam daarom tot stand, toen Heidegger in onze generatie op de betekenis van het Griekse woord voor waarheid teruggreep. Het was geen oorspronkelijk inzicht van Heidegger, dat aletheia eigenlijk onverborgenheid betekent. Maar Heidegger heeft ons geleerd wat het voor het denken van het Zijn betekende, dat het de verborgenheid en de verholenheid van de dingen is waarop de waarheid als een prooi veroverd moet worden. Verborgenheid en verholenheid-beide horen te zamen. De dingen houden zich uit zichzelf op in de verborgenheid; "de natuur houdt ervan, zich te verbergen", zou Herakleitos gezegd hebben. Zo ook echter behoort de verholenheid tot het menselijk doen en spreken. Want het menselijke spreken geeft niet al het ware door, het kent ook schijn, bedrog en voorwendsel. Er bestaat dus een oorspronkelijke samenhang tussen het ware Zijn en het ware spreken. De onverborgenheid van het zijnde komt in de onverholenheid van de uitdrukking ter sprake.

De spreekwijze die dit verband het zuiverst laat uitkomen, is de les. We moeten ons daarbij duidelijk maken, dat het voor ons zeker niet de enige en pri- 
maire ervaring van het spreken is, dat het leert; het is echter wel die ervaring van spreken waaraan door de Griekse filosofen in de eerste plaats gedacht is, en die de wetenschap met al haar mogelijkheden opgeroepen heeft. Spreken, logos, wordt vaak ook als rede vertaald, terecht in zoverre het voor de Grieken snel plausibel was dat het de dingen zelf in hun begrijpelijkheid zijn die in het spreken primair bewaard en verborgen zijn. Het is de ratio van de dingen zelf die zich in een specifieke manier van spreken laat weergeven en mededelen. Deze manier van spreken noemt men uitdrukking of oordeel. De Griekse uitdrukking ervoor is apophansis, de latere logica heeft er het begrip van het oordeel voor gevormd. Het oordeel is hierdoor gekenmerkt dat het - in onderscheid van alle andere manieren van spreken - slechts waar wil zijn, zich uitsluitend daaraan meet, dat het een zijnde onthult zoals het is. Er bestaat het bevel, er bestaat het verzoek, de verwensing, er bestaat dat heel raadselachtige fenomeen van de vraag, waarover nog iets te zeggen zal zijn, kortom er bestaan ontelbare vormen van spreken, die allemaal ook zo iets als waar-zijn bevatten. Maar allemaal zijn ze er niet uitsluitend door gekenmerkt, een zijnde te tonen zoals het is.

Wat is dat voor een ervaring, die de waarheid helemaal op het tonen in het spreken situeert? Waarheid is onverborgenheid. Het laten-voorliggen van het onverborgene, het onthullen is de zin van het spreken. Men legt iets voor en op deze wijze ligt het voor, aan de andere net zo medegedeeld als het aan jezelf voor ogen ligt. Zo zegt Aristoteles: een oordeel is waar, als het te zamen laat voorliggen, wat ook in de zaak te zamen voorligt; een oordeel is vals, als het in het spreken te zamen laat voorliggen, wat in de zaak te zamen niet voorligt. Waarheid van het spreken wordt zo bepaald als beantwoording van de uitspraak aan de zaak, dit wil zeggen als overeenstemming van het door middel van het spreken laten voorliggen met de zaak die voorligt. Vandaar stamt de definitie van de waarheid die ons uit de logica zeer vertrouwd is, namelijk dat ze adaequatio intellectus ad rem is. Daarbij is als onbetwijfelbaar vanzelfsprekend vooropgesteld, dat het spreken, dit wil zeggen de intellectus die zich in het spreken uitspreekt, de mogelijkheid heeft zo overeen te stemmen, dat slechts dat wat voorligt, ter sprake komt in dat wat ze zegt, dat ze dus werkelijk de dingen zo toont zoals ze zijn. We noemen dat in de wijsbegeerte met het oog op het feit dat er nog andere mogelijkheden van waarheid van een uitspraak bestaan, de oordeelswaarheid. De plaats van de waarheid is het oordeel.

Dit mag een eenzijdige bewering zijn, waarvoor Aristoteles geen ondubbelzinnige getuige is. Ze heeft zich echter uit de Griekse leer van de logos ontwikkeld en ligt aan haar ontwikkeling tot het moderne wetenschapsbegrip ten grondslag. De wetenschap die door de Grieken geschapen is, vertoont zich op de eerste plaats heel anders, dan dat het strookt met ons wetenschapsbegrip. Niet natuurwetenschap, laat staan geschiedenis, maar wiskunde is de eigenlijke wetenschap. Want haar object is een zuiver rationeel zijn, en zij is in zoverre een 
voorbeeld voor alle wetenschap, omdat zij in een gesloten deductieve samenhang voor te stellen is. Voor de moderne wetenschap daarentegen is het kenmerkend, dat voor haar de wiskundige niet door het zijn van haar objecten maar als volmaakste manier van kennen tot voorbeeld strekt. De moderne vorm van de wetenschap voltrekt een beslissende breuk met de wetensvormen van het Griekse en het christelijke avondland. Het is de idee van de methode die nu overwegend wordt. De methode in de moderne zin is echter bij alle verscheidenheid die ze in de verschillende wetenschappen kan hebben, algemeen geldig. Het kennisideaal dat door het methodebegrip gekenmerkt wordt, bestaat daarin, dat we een weg van het kennen zo bewust opgaan, dat het steeds mogelijk is hem na te gaan. 'Methodos' betekent een weg om na te gaan. Steeds weer te kunnen nagaan hoe men gegaan is, dat is methodisch en kenmerkt de werkwijze van de wetenschap. Juist daarmee echter wordt noodzakelijk een beperking opgelegd aan wat zich in het algemeen met aanspraak op waarheid kan voordoen. Wanneer slechts controleerbaarheid - onder welke vorm ook - de waarheid (veritas) van iets uitmaakt, dan is de maatstaf waarmee kennis gemeten wordt, niet meer haar waarheid maar haar zekerheid. Daarom geldt, sedert de klassieke formulering van de zekerheidsregel van Descartes, als het eigenlijke ethos van de moderne wetenschap, dat zij slechts dat toelaat als kennis die aan de waarheidsvoorwaarden voldoet, wat aan het ideaal van zekerheid voldoet.

Dit wezen van de moderne wetenschap is bepalend voor ons gehele leven. Want het verificatie-ideaal, de begrenzing van het weten tot het controleerbare, vindt zijn vervulling in het namaken. Zo is het de moderne wetenschap, uit wiens wetmatige voortgang de hele wereld van de planning en van de techniek voortspruit. Het probleem van onze beschaving en van de ellende die haar vertechnisering ons aandoet, is niet zomaar daarin gelegen, dat de juiste tusseninstantie tussen de kennis en de praktische toepassing ontbreekt. De kenniswijze van de wetenschap is zelf juist zo, dat ze zo een instantie onmogelijk maakt. Ze is zelf techniek.

$\mathrm{Nu}$ is eigenlijk dat bedenkelijk aan de wijziging die het wetenschapsbegrip sinds het begin van de moderne tijden ondergaan heeft, dat in deze wijziging tóch de fundamentele aanzet van het Griekse zijnsdenken behouden blijft. De moderne fysica vooronderstelt de antieke metafysica. Dat Heidegger deze vér teruggaande beinvloeding van het westerse denken ingezien heeft, maakt zijn eigenlijke betekenis voor het historisch zelfbewustzijn van onze tijd uit. Dit inzicht snijdt immers alle romantische restauratiepogingen van oudere idealen, zowel de middeleeuwse als de hellenistisch-humanistische, de pas af, doordat ze de onvermijdelijkheid van de geschiedenis van de westerse beschaving vaststelt. Ook het door Hegel ontworpen schema van een filosofie van de geschiedenis en van een geschiedenis van de filosofie kan nu niet meer volstaan, omdat volgens Hegel de Griekse filosofie slechts een speculatieve vooroefening is van wat in 
het zelfbewustzijn van de geest zijn moderne voltooiing vond. Het speculatieve idealisme en zijn eis van een speculatieve wetenschap is tenslotte zelf een machteloze restauratie gebleven. De wetenschap is - hoeveel men er ook op afgeeft - de alpha en de omega van onze beschaving.

\section{Waarheid buiten de wetenschap}

$\mathrm{Nu}$ is het niet zo, alsof de filosofie daar pas tegenwoordig een probleem begint in te zien. Veeleer ligt hier een zo open kernprobleem voor ons hele beschavingsbewustzijn, dat de moderne wetenschap door de kritiek op de 'school' als door haar schaduw gevolgd wordt. Filosofisch stelt de vraag zich zo: kan men, en in welke zin en op welke manier, achter het weten dat in de wetenschappen gethematiseerd wordt, teruggaan? Dat de praktische levenservaring van ieder van ons deze teruggang permanent voltrekt, behoeft geen nadruk. Men kan er steeds op hopen, dat iemand anders inziet wat men voor waar houdt, ook als men het niet kan bewijzen. Ja, men zal zelf niet steeds de weg van het bewijzen mogen beschouwen als de juiste weg waarlangs men iemand anders tot inzicht brengt. De grens van de objectiveerbaarheid, waaraan de uitdrukking volgens haar logische vorm gebonden is, wordt door ons allen steeds overschreden. We leven permanent in mededelingsvormen voor wat niet objectiveerbaar is, die de taal, ook die van de dichters, ons ter beschikking stelt.

Het is evenwel de aanspraak van de wetenschap, de toevalligheid van de subjectieve ervaring door objectieve kennis, de taal van de dubbelzinnige symboliek door de ondubbelzinnigheid van het begrip te overwinnen. De vraag is echter: bestaat er binnen de wetenschap als zodanig een grens voor de objectiveerbaarheid, die in het wezen van het oordeel en van de waarheid van de uitdrukking zelf ligt?

Het antwoord op deze vraag is geenszins vanzelfsprekend. Er bestaat een zeer grote, in haar betekenis zeker niet gering te achten beweging in de hedendaagse filosofie, voor wie dit antwoord vaststaat. Ze gelooft dat het hele geheim en de uitsluitende taak van de filosofie erin bestaat, de uitdrukking zó exact te vormen, dat ze werkelijk in staat is, het bedoelde ondubbelzinnig mee te delen. De filosofie zou een tekensysteem moeten uitbouwen dat niet van de metaforische dubbelzinnigheid van de natuurlijke talen afhangt, - ook niet van de meertaligheid van de moderne cultuurvolkeren in het algemeen en de daaruit voortvloeiende permanente aanleidingen tot misverstand en misvattingen, maar dat de ondubbelzinnigheid en de precisie van de wiskunde zou evenaren. De mathematische logica geldt hier als weg om alle problemen op te lossen die de wetenschap tot hiertoe aan de filosofie overliet. Deze stroming, die vanuit het geboorteland van het nominalisme in de hele wereld doordringt, is een heropleving van de ideeën uit de achttiende eeuw. Als filosofie lijdt ze weliswaar 
aan een immanente logische moeilijkheid. Dat begint ze langzamerhand zelf in te zien. Men kan aantonen dat de introductie van conventionele tekensystemen zich nooit door middel van het systeem zelf dat in deze conventies besloten ligt, kan voltrekken, - dat dus iedere introductie van een kunstmatige taal reeds een andere taal waarin men spreekt, vooropstelt. Het is het logische probleem van de meta-taal dat hier op zijn plaats is. Maar daarachter steekt nog iets anders: de taal die we spreken en waarin we leven, heeft een voortreffelijke positie. Terzelfder tijd is ze inhoudelijk voorgegeven voor elke nakomende logische analyse. En ze is dat niet als een loutere som van uitdrukkingen. Want de uitdrukking die de waarheid wil zeggen, moet nog aan heel andere voorwaarden voldoen dan die van de logische analyse. $\mathrm{Zijn}$ aanspraak op onverborgenheid bestaat niet slechts in het laten voorliggen van het voorliggende. Het volstaat niet dat wat voorligt, in de uitdrukking ook voorgelegd wordt. Want het probleem is juist dat alles zo voorligt, dat het in het spreken voorgelegd kan worden, en of niet doordat men voorlegt wat men kan voorleggen, de erkenning verhinderd wordt van wat nochtans is en ervaren wordt.

Ik meen dat de geesteswetenschappen voor dit probleem een zeer welsprekende getuigenis afleggen. Ook daar is veel dat onder het methodebegrip van de moderne wetenschap ondergebracht kan worden. Ieder van ons moet de verifieerbaarheid van alle kennis in de mate van het mogelijke als ideaal laten gelden. Maar we moeten toegeven dat dit ideaal zeer zelden bereikt wordt en dat die onderzoekers die ernaar streven dit ideaal zo precies mogelijk te bereiken, ons meestal niet de werkelijk belangrijke dingen te zeggen hebben. Zo komt het dat er in de geesteswetenschappen iets bestaat dat in de natuurwetenschappen op dezelfde manier niet denkbaar is, dat namelijk de onderzoeker soms uit een boek van een dilettant meer kan leren dan uit de boeken van andere onderzoekers. Dit is natuurlijk beperkt tot uitzonderingsgevallen, maar dat er zo bestaan, wijst erop dat er zich hier een verband tussen inzicht in de waarheid en uitdrukbaarheid voordoet, dat niet aan de verifieerbaarheid van uitdrukkingen te meten is. We kennen dat zozeer uit de geesteswetenschappen dat we een gegrond wantrouwen koesteren tegen een bepaald type van wetenschappelijke werken, die de methode waarmee ze verkregen zijn, vooraan en achteraan, maar vooral onderaan, dit wil zeggen in de noten, al te duidelijk tonen. Wordt daar werkelijk naar iets nieuws gevraagd? Wordt daar werkelijk iets gekend ? Of wordt daar slechts de methode waarmee men kent, zo goed nagevolgd en in haar uiterlijke vormen geimiteerd, dat op deze manier de indruk van een wetenschappelijk werk ontstaat ? We moeten toegeven, dat omgekeerd de grootste en vruchtbaarste prestaties in de geesteswetenschappen zeer ver op het verifieerbaarheidsideaal vooruit lopen. Dit wordt filosofisch belangwekkend, want de mening is immers niet dat de niet-originele ondérzoeker zich uit een soort bedoeling tot misleiding als een geleerde voordoet, en dat omgekeerd de vruchtbare onder- 
zoeker in revolutionair protest alles zou moeten opzijschuiven wat tot hiertoe in de wetenschap gegolden heeft. Veeleer kondigt zich hier een zakelijk verband aan, waarin dat wat wetenschap mogelijk maakt, terzelfder tijd ook de vruchtbaarheid van wetenschappelijke kennis kan hinderen. Het gaat hier om een principieel verband tussen waarheid en onwaarheid.

Dit verband toont zich daarin, dat het loutere laten-voorliggen van wat voorligt, weliswaar waar is, dit wil zeggen openlegt zoals het is, maar steeds tegelijk afbakent, wat voortaan nog als zinvolle vraag gesteld en in voortschrijdende kennis opengelegd kan worden. Het is niet mogelijk, steeds maar in de kennis vooruit te schrijden zonder daarbij ook mogelijke waarheid uit handen te geven. Hierbij gaat het geenszins om een kwantitatieve verhouding, alsof we steeds slechts een eindige omvang van weten kunnen vasthouden. Het is veeleer niet slechts zo, dat we steeds tegelijk waarheid verbergen en vergeten, terwijl we waarheid kennen, maar het is zo, dat we noodzakelijk binnen de perken van onze hermeneutische situatie bevangen zijn, als we naar waarheid vragen. Dit betekent echter, dat we heel wat waars, helemaal niet kunnen kennen, omdat vooroordelen ons, zonder dat we het weten, inperken. Ook in de praktijk van het wetenschappelijk werk bestaat er zo iets als 'mode'.

We weten welke geweldige macht en dwingende kracht de mode is. Nu klinkt het woord 'mode' verschrikkelijk slecht in de wetenschap, want vanzelfsprekend is het onze pretentie, dat wat slechts de mode eist, naast ons neer te leggen. Maar de vraag is echter of het niet in het wezen van de zaak ligt, dat er ook in de wetenschap mode bestaat. Of de wijze waarop wij de waarheid inzien, noodzakelijk met zich meebrengt, dat iedere stap voorwaarts ons verder verwijdert van de vooronderstellingen waarvan we uitgegaan zijn, ze in de duisternis van de vanzelfsprekendheid laat terugzinken en het precies daardoor oneindig moeilijk maakt om boven deze vooronderstellingen uit te komen, nieuwe vooronderstellingen te beproeven en daardoor werkelijk nieuwe inzichten te verwerven. Er bestaat zo iets als een bureaucratisering, niet alleen van het leven maar ook van de wetenschappen. Wij vragen: ligt dat in het wezen van de wetenschap of is dat slechts een soort cultuurziekte van de wetenschap, zoals wij op andere gebieden gelijkaardige ziekteverschijnselen kennen, wanneer wij bijvoorbeeld die reusachtige kasten van onze administratiegebouwen en verzekeringsinstellingen bewonderen? Misschien ligt dat werkelijk in het wezen van de waarheid zelf, zoals de Grieken ze voor het eerst gedacht hebben, en daarmee ook in het wezen van onze kennismogelijkheden, zoals de Griekse wetenschap ze voor het eerst geschapen heeft. De moderne wetenschap heeft immers slechts, zoals we boven zagen, de vooronderstellingen van de Griekse wetenschap geradicaliseerd, die in de begrippen van de 'logos', van de uitdrukking, van het oordeel toonaangevend zijn. Het filosofisch onderzoek, dat in onze generatie in Duitsland door Husserl en Heidegger bepaald is, heeft getracht, daarover rekenschap te geven, doordat 
het vroeg, wat de waarheidsvoorwaarden van de uitdrukking zijn die boven het logische uitgaan. Ik geloof dat men principieel kan zeggen: er kan geen uitdrukking bestaan die eenvoudigweg waar is.

Deze stelling is welbekend als het uitgangspunt van de Hegeliaanse zelfconstructie van de rede door middel van de dialectiek. "De vorm van de zin is niet geschikt om speculatieve waarheden uit te spreken." Want de waarheid is het geheel. Deze kritiek op de uitdrukking en de zin, die Hegel uitoefent, is evenwel zelf nog op een ideaal van totale uitdrukbaarheid betrokken, namelijk om de totaliteit van het dialectisch proces, die in het absolute weten geweten wordt. Een ideaal dat de Griekse aanzet nogmaals tot radicale uitvoering brengt, Niet bij Hegel, maar pas met het oog op de wetenschappen van de historische ervaring, die zich tegen Hegel in doorzetten, laat zich de grens die aan de uitdrukkingslogica vanuit haarzelf gesteld is, werkelijk bepalen. Zo hebben dan ook de werken van Dilthey, die aan de ervaring van de historische wereld gewijd zijn, in de nieuwe aanzet van Heidegger een belangrijke rol gespeeld.

\section{Waarheid als antwoord}

Er bestaat geen uitdrukking die men alleen afgaande op de inhoud die ze laat zien, kan opvatten, als men ze in haar waarheid wil begrijpen. Iedere uitdrukking is gemotiveerd. Iedere uitdrukking heeft vooronderstellingen die ze niet onder woorden brengt. Slechts wie deze vooronderstellingen erbij denkt, kan de waarheid van een uitdrukking werkelijk beseffen. Nu beweer ik: de laatste logische vorm van zo een motivatie voor elke uitdrukking is de vraag. Niet het oordeel, maar de vraag heeft in de logica prioriteit, zoals ook de Platoonse dialoog en de dialectische oorsprong van de Griekse logica historisch getuigen. De prioriteit van de vraag tegenover de uitdrukking betekent echter, dat de uitdrukking wezenlijk antwoord is. Er bestaat geen uitdrukking die niet een soort antwoord is. Vandaar dat er ook geen begrijpen van een of andere uitdrukking bestaat dat niet in het verstaan van de vraag waarop ze antwoordt, zijn uitsluitende maatstaf vindt. Wanneer men dat uitspreekt, klinkt het als een vanzelfsprekendheid en is het iedereen uit zijn levenservaring bekend. Als iemand iets beweert dat men niet verstaat, dan tracht men zich duidelijk te maken, hoe hij daartoe komt, welke vraag hij zich gesteld heeft, waarop zijn uitdrukking een antwoord is. En als het een uitdrukking is die waar moet zijn, dan moet men het zelf met de vraag proberen waarop ze een antwoord wil zijn. Het is zeker niet steeds gemakkelijk, $d e$ vraag te vinden waarop een uitdrukking werkelijk antwoord geeft. Het is vooral daarom niet gemakkelijk, omdat ook een vraag nog eens niet eenvoudig het eerste is waarop we ons naar believen kunnen verplaatsen. Want iedere vraag is zelf antwoord. Dat is de dialectiek waarin we ons hier verstrikken. Iedere vraag is gemotiveerd. Ook háár betekenis is nooit volledig in haar- 
zelf aan te treffen. Wanneer ik eerder op de problemen van het alexandrinisme wees, die onze wetenschappelijke cultuur bedreigen in zoverre de oorspronkelijkheid van het vragen erin bemoeilijkt wordt, dan ligt er hier de wortel van. Het beslissende, wat in de wetenschap de onderzoeker pas kenmerkt, is: vragen te zien. Vragen zien betekent echter: kunnen openbreken wat als een gesloten en ondoordringbare laag van plat getrapte vooroordelen ons hele denkẹn en kennen beheerst. Zó kunnen openbreken, dat op deze manier nieuwe vragen gezien en nieuwe antwoorden mogelijk worden, dat kenmerkt de onderzoeker. Iedere uitdrukking heeft haar betekenishorizon hierin, dat ze uit een vraagsituatie stamt.

Wanneer ik in deze samenhang het begrip 'situatie' gebruik, dan wijst dat erop, dat de wetenschappelijke vraag en de wetenschappelijke uitdrukking slechts het bijzondere geval zijn van een veel algemener verband dat in het situatiebegripgeviseerd wordt. De samenhang tussen situatie en waarheid is reeds in het Amerikaans pragmatisme gevlochten. Daar verstaat men als het eigenlijk kenmerk van de waarheid het klaarkomen met een situatie. De vruchtbaarheid van een inzicht wordt daardoor bewezen, dat het een problematische situatie uit de weg ruimt. Ik meen dat de pragmatische draai die de zaak hier neemt, niet voldoende is. Dit blijkt reeds daaruit, dat het pragmatisme alle zogenoemde filosofische, metafysische vragen gewoon opzijschuift, daar het er slechts zou op aankomen, telkens met de situatie klaar te komen. Om vooruit te komen zou het erop aankomen, de hele dogmatische ballast van de traditie af te werpen. Dat anzie ik als een kortsluiting. De prioriteit van de vraag, waarover ik sprak, is geen pragmatische. En even weinig is het antwoord dat waar is, aan de maatstaf van de gevolgen op handelingsvlak gebonden. Het pragmatisme heeft echter wel daarin gelijk, dat men boven de formele betrekking waarin de vraag tot de zin van de uitdrukking staat, moet uitgaan. We treffen het medemenselijke fenomeen van de vraag in zijn volle concretie, wanneer we ons van de theoretische relatie van vraag en antwoord die kenmerkend is voor de wetenschap, afwenden en nadenken over de situaties in het bijzonder waarin mensen genoemd en ondervraagd worden en zich zelf ondervragen. Daar wordt duidelijk dat het wezen van de uitdrukking in zichzelf een uitbreiding ondervindt. Niet alleen dat de uitdrukking steeds antwoord is en naar een vraag verwijst, maar zowel vraag als antwoord hebben in hun gemeenschappelijk uitdrukkingskarakter een hermeneutische functie. Ze zijn beide aanspreking. Dat moet niet alleen maar betekenen, dat er steeds ook iets van onze tijdgenoten in de inhoud van onze uitdrukkingen meespeelt. Dat is weliswaar juist. Maar niet daarover gaat het, maar wel hierover dat er maar van waarheid in de uitdrukking sprake kan zijn, in zoverre ze aanspreking is. Want-de situatie-horizon die de waarheid van een uitdrukking bepaalt, omvat mede diegene aan wîe met de uitdrukking iets gezegd wordt. 
De moderne existentiefilosofie heeft deze conclusie met volle bewustzijn getrokken. Ik herinner aan de filosofie over de communicatie bij Japsers, die haar 'pointe' daarin heeft, dat het dwingende van de wetenschap daar een einde vindt waar de eigenlijke vragen van het menselijk bestaan, eindigheid, historiciteit, schuld, dood - kortom, de zogenoemde grenssituaties - bereikt zijn. Hier is communicatie niet meer overlevering van kennis door middel van dwingende bewijzen, maar een soort omgang van existentie met existentie. Wie spreekt, wordt zelf aangesproken en antwoordt als een ik aan een jij, omdat hij voor zijn jij zelf een jij is. Het lijkt me weliswaar onvoldoende, in de tegenstelling tot het begrip van de wetenschappelijke waarheid, die anoniem, algemeen en dwingend is, een tegenbegrip van existentiewaarheid te vormen. Veeleer steekt achter deze binding van de waarheid aan mogelijke existentie, die Jaspers benadrukt, een algemener filosofisch probleem.

Hier heeft Heideggers vraag naar het wezen van de waarheid het probleemgebied van de subjectiviteit pas werkelijk overschreden. Zijn denken heeft van het 'werktuig', over het 'werk' tot het 'ding' zijn weg afgelegd, een weg die de vraag van de wetenschap, ook die van de historische wetenschappen, ver achter zich laat. De tijd is gekomen om daarbij niet te vergeten, dat de historiciteit van het Zijn ook daar heerst, waar Dasein zich van zichzelf bewust is en waar het zich als wetenschap historisch gedraagt. De hermeneutiek van de historische wetenschappen, die eertijds in de romantiek en de historische school, van Schleiermacher tot Dilthey, ontwikkeld werd, wordt tot een geheel nieuwe opgave, als men ze, daarin Heidegger volgend, buiten de problematiek van de subjectiviteit plaatst. De enige die hier voorbereidend werk gedaan heeft, is Hans Lipps, wiens hermeneutische logica weliswaar geen werkelijke hermeneutiek biedt, maar wel de bindende kracht van de taal tegen haar logische nivellering in zegevierend doet uitkomen.

\section{Geschiedenis en waarheid}

Dat, zoals boven vermeld, iedere uitdrukking haar situatiehorizon en haar aansprekingsfunctie heeft, is dus slechts de grondslag voor de verdergaande conclusie, dat de eindigheid en de historiciteit van elke uitdrukking op de principiële eindigheid en historiciteit van ons bestaan teruggaat. Dat een uitdrukking meer is dan slechts het voor-de-geest-roepen van aanwezige feiten, betekent vooral dat ze tot het geheel van een historische existentie behoort en met alles wat daarin tegenwoordig kan zijn, gelijktijdig is. Wanneer we zinnen die ons overgeleverd zijn, willen verstaan, dan maken we historische overwegingen waaruit te voorschijn moet komen, waar en hoe deze zinnen uitgesproken zijn, wat hun eigenlijke motivatie-achtergrond en daarmee hun eigenlijke betekenis is. Zo moeten we, wanneer we een zin als zodanig willen begrijpen, zijn historische 
horizon mede voor de geest roepen. Maar klaarblijkelijk volstaat dat niet om te beschrijven wat we werkelijk doen. Want onze houding tegenover de overlevering neemt er geen genoegen mee, dat we haar willen verstaan, doordat we door middel van historische reconstructie haar betekenis opsporen. Dat kan de filoloog doen, maar zelfs de filoloog zou kunnen bekennen dat wat hij in werkelijkheid doet, meer is dan dit. Als de Oudheid niet klassiek geweest was, dit wil zeggen voorbeeldig voor al het spreken, denken en dichten, dan zou er geen klassieke filologie zijn. Voor alle andere filologie geldt dit echter ook, dat daarin de fascinatie van het andere, vreemde of verre werkzaam is, dat zich voor ons ontsluit. De eigenlijke filologie is niet alleen geschiedenis, en wel daarom, omdat ook de geschiedenis zelf in werkelijkheid een ratio philosophandi is, een weg om waarheid te kennen. Wie zich toelegt op historische studies, is steeds mede door het feit bepaald, dat hijzelf geschiedenis ervaart. Geschiedenis wordt daarom steeds weer opnieuw geschreven, omdat het heden ons bepaalt. Het gaat in haar niet slechts om reconstructie, om het tegenwoordig-stellen van het verleden, maar het eigenlijke raadsel en probleem van het verstaan is, dat wat zo gelijktijdig gemaakt is, altijd al met ons gelijktijdig was, als iets dat waar wil zijn. Wat loutere reconstructie van verleden betekenis scheen, versmelt met wat ons onmiddellijk als waar aanspreekt. Ik houd het voor een van de belangrijkste verbeteringen die we aan het zelfbegrip van het historisch bewustzijn moeten aanbrengen, dat de gelijktijdigheid een hoogst dialectisch probleem blijkt te zijn. Historische kennis is nooit loutere vertegenwoordiging. Maar ook het verstaan is geen loutere naconstructie van een betekenisconstructie, bewuste verklaring van een onbewuste productie. Elkaar verstaan betekent veeleer, elkaar in iets verstaan. Het verleden verstaan betekent dan ook: het beluisteren in wat het ons als geldig wil zeggen. De prioriteit van de vraag ten opzichte van de uitdrukking betekent voor de hermeneutiek dat men iedere vraag die men verstaat, zelf vraagt. Versmelting van de tegenwoordige horizon is het werk van de historische geesteswetenschappen. Ze doen daarmee echter slechts wat we altijd al doen, doordat we bestaan.

Wanneer ik het begrip 'gelijktijdigheid' gebruikte, dan deed ik dat om een gebruikswijze van dit begrip mogelijk te maken die door Kierkegaard voorgesteld is. Hij was het, die de waarheid van de christelijke verkondiging als 'gelijktijdigheid' karakteriseerde. Voor hem stelde zich de eigenlijke opgave van het christen-zijn zo, dat de afstand van het verleden in gelijktijdigheid opgeheven werd. Wat bij Kierkegaard uit theologische gronden in de vorm van de paradox geformuleerd werd, is echter zakelijk iets wat steeds voor onze verhouding tot de overlevering en tot het verleden geldt. Ik meen dat de taal de voortdurende synthese tussen verleden horizon en tegenwoordige horizon tot stand brengt. We verstaan elkaar, doordat we met elkaar praten, doordat we voortdurend langs elkaar heen praten en toch tenslotte in het gebruik van de woorden de 
met de woorden gezegde dingen samen naar voren brengen. Het is zo, dat de taal haar eigen historiciteit heeft. Ieder van ons heeft zijn eigen taal. Twee mensen die hun leven met elkaar delen, hebben hun taal. Het probleem van een voor allen gemeenschappelijke taal bestaat helemaal niet, maar er bestaat slechts dit wonder, dat we, hoewel we allemaal een verschillende taal hebben, elkaar toch over de grenzen van de individuen, van de volkeren en van de tijden heen kunnen verstaan. Dit wonder is kennelijk niet los te koppelen van het feit dat ook de dingen waarover we spreken, zich als iets gemeenschappelijks voor ons vertonen, doordat we erover spreken. Hoe een zaak is, blijkt als het ware slechts wanneer we erover praten. Wat we met waarheid bedoelen, openbaarheid, onverborgenheid van de dingen, heeft dus zijn eigen tijdelijkheid en historiciteit. Wat we in al het streven naar waarheid met verbazing waarnemen, is, dat we de waarheid niet kunnen spreken zonder anspreking, zonder antwoord en dus zonder de gemeenschappelijkheid van de verkregen overeenstemming. Het meest verwonderlijke aan het wezen van de taal en van het gesprek is echter, dat ook ikzelf niet gebonden ben aan wat ik meen, wanneer ik met anderen over iets spreek, dat niemand van ons de hele waarheid in zijn mening omvat, maar dat wel de hele waarheid ons beiden in onze afzonderlijke mening kan omvatten. Een hermeneutiek die beantwoordt aan onze historische existentie, zou als opgave hebben, deze betekenisrelaties van taal en gesprek te ontwikkelen, die over ons hoofd heen spelen. 


\section{PERSONALIA}

Hans-Georg Gadamers Gesammelte Werke, dat tien volumes zal beslaan, verschijnt sedert het voorjaar bij J.C.B. Mohr (Tübingen); in 1983 publiceerde hij ook nog Lob der Theorie (Suhrkamp)

Jacques de Visscher publiceerde in het voorjaar Melodie en gemoed. De vruchtbare grenzen van de muziek (De Nederlandsche Boekhandel)

Ad Peperzak is onder meer de auteur van Systematiek en geschiedenis (Samsom)

\section{Binnenkort in DE UIL VAN MINERVA}

Piet van Eeckhaut, Recht en ethiek

Roger Thibau, Een interpretatie van Plato's Symposium

Luc Vanneste, Dialektiek : revolutie zonder tegenspoed

Raoul Bauer, Kaleidoskoop van de geschiedenis

Max Stirner, Ik heb Mijn Zaak op Niets gevest/Een Mensenleven

Friederich Nietzsche, Proeve van zelfkritiek

\section{AGENDA}

Op maandag 14 oktober spreekt voor de Gentse Kultuurvereniging Samuel IJsseling over Demokratie en totalitarisme te $20 \mathrm{u}$ in het auditorium van de HBK-Spaarkas (Lammerstraat 18 te Gent). Voor die zelfde vereniging spreekt op maandag 2 december de historicus Raoul Van Caenegem over Het ontstaan van de demokratie in Engeland en haar actuele betekenis.

De Duitse filoso of Walter Biemel houdt in november een drietal lezingen in Gent: op maandag 4 november te $20 \mathrm{u}$ over Martin Heidegger (voor de Gentse Kultuurvereniging, auditorium van de HBK-Spaarkas, Lammerstraat 18); op dinsdag 5 november te $10 \mathrm{u}$ in het Hoger Instituut Sint-Lucas (Zwartezusterstraat 34, Gent) over de beeldhouwer Norbert Kricke; op donderdag 7 november te $18 \mathrm{u}$ in de Ecole des Hautes Etudes (Korenlei 21, Gent) over De tijd in de moderne roman. Walter Biemel zal zijn voordrachten in het Frans houden.

Nog steeds te Gent, in het kader van de studie van de Middeleeuwse kultuur aan het Hoger Architectuurinstituut Sint-Lucas (Zwartezusterstraat 34 te 20u) zijn twee lezingen voorzien : op maandag 21 oktober : Felix Claus over de Middeleeuwse copiist en op maandag 25 november: Maur Standaert over de Cisterciënzer Mystiek.

Het Studiecentrum voor Godsdienstwetenschappen van de Gentse Rijksuniversiteit voorziet een aantal lezingen over Recente ontwikkelingen in religie (Auditorium B, Blandijnberg 2 Gent) : op maandag 21 oktober spreekt Chris Vonck over Recente ontwikkelingen in het Protestantisme; op maandag 18 november spreekt Jaap Kruithof over Sacraliteit; op maandag 9 december spreekt Willy Bock over Changements récents du judaisme; alle lezingen gaan door om $20 \mathrm{u}$. 